\title{
INFLUENCES OF SELF-EFFICACY AND JOB SATISFACTION TO ORGANIZATIONAL COMMITMENT
}

\author{
Eka FRANSISKA, \\ Universitas Sumatera Utara, Indonesia
}

ZULKARNAIN,

Universitas Sumatera Utara, Indonesia

Eka Danta Jaya GINTING, Universitas Sumatera Utara, Indonesia

(C) The Author(s) 2020

\section{ABSTRACT}

This research was conducted to find out how self-efficacy influences job satisfaction and organizational commitment towards employees. This research uses a quantitative approach to explain the relationships between variables in the hypothesis. This research method using the questionnaire as a tool of data collection are propagated to the 47 respondents sampled while the population of respondents from employees of PT. PGAS Solution Medan by using multiple linear regression analysis. The results showed that there was a significant positive influence between self-efficacy against organizational commitment, there is a significant positive influence between job satisfactions towards organizational commitment, and there is a positive influence significantly between self- efficacy and job satisfaction against the organizational commitment of employees.

Self-efficacy shows the individual's belief that he can perform the desired action by certain situations successfully. This is in line with Bandura's own opinion which states that selfconfidence is an opinion or belief that someone has about his ability to display a form of behavior, in this case related to the situation faced by a person and places it as a cognitive element in learning.

\section{2020.All rights reserved}

\section{ARTICLE HISTORY}

Received: $28 / 05 / 2020$

Accepted:05/09/2020

Published online:30/10/2020

\section{KEYWORDS}

Self-Efficacy, job satisfaction, organizational commitment, quantitative approach, employees 


\section{Introduction}

When the company offers a job and job applicants accept the offer, the job applicant has become part of the company. By being part of the company, employees are educated to commit to the company's goals. It is not surprising that employee commitment is a fundamental activity for the success of an Organization (Mohamud et al, 2018). There are many reasons why an organization must try to increase the organizational commitment of its employees. For example, many studies have found that the more employees are committed to the company; the employee will try to better accomplish their tasks. Employees with sense of employee commitment are less likely to engage in withdrawal behaviour and more willing to accept change (Irefin \& Mechanic, 2014). Companies needed to strengthen their employees' commitment towards organization in order to enhance organizational performance (Andrew, 2017).

Self-efficacy (SE) is a person's reality regarding his ability to do certain specific tasks. SE may be defined as an individual's belief in his or her ability to succeed in a specific situation or accomplish a specific task (Yokoyama, 2019). Selfefficacy is a self-concept and is related to one's perception of ability and expertise in dealing with a particular task. Self-efficacy helps to develop educational talent with involvement in learning activities. Through these activities, the level of achievement and motivation usually increases and has positive influence (Ifdil et al, 2019). Peter has the opinion that self-efficacy is an attitude or feeling of confidence in one's own abilities so that the person concerned is not overly anxious in his actions, can feel free to do the things he likes and is responsible for his actions, warm and polite in interacting with people others, can accept and respect others, have the drive to excel and recognize their strengths and weaknesses.

\section{Aspects of Self-Efficacy}

According to Bandura (2010), there are four aspects that can be used in measuring self-efficacy, namely:

1) Enactive Mastery Experience is a learning experience gained through learning by doing or experiential learning. Enactive mastery experience is one of the sources that contribute the most to the formation of self-efficacy, because this aspect is based on personal success experiences. 
2) Vicarious Experience, is an assessment of self-efficacy that is largely obtained through experience or results achieved by others that serve as models. Learning experiences are gained through observing the appearance of others (modeling) and through clarity of instructions given by the model. When the model is considered successful in doing a job, then self-efficacy will increase and vice versa failure of the role model will reduce self-efficacy.

3) Verbal Persuasion is a belief in the ability of self - obtained from others that is conveyed orally. Confidence obtained through this process is weak and for a short period of time. In addition, self-confidence can be obtained through the statements of others that are conveyed continuously, so that relatively formed beliefs are formed.

4) Emotional Arousal is the threshold of emotional emotion in dealing with a particular situation or situation. The threshold of emotional fallout at a low level makes individuals easily anxious when solving a problem. The more complex the problem that must be solved, he will be more anxious because he feels unable to solve it, on the contrary if the threshold of emotional emotion is high then he is not easily distracted when facing a problem. He will remain calm and try to solve it properly.

\section{Effect of Self-Efficacy on Employee Organizational Commitment}

Organizational commitment (OC), is defined as "the relative strength of an individual's identification with and involvement in a particular organization (AlJabari \& Ghazzawi, 2019). Organizational Commitment (CO) is, in general term, an employee's sense of attachment and loyalty to the work organization whit which the employee is associated (Tuna et al, 2016) Organizational commitment in a company is an important factor towards the goals to be achieved by the company, so this commitment can provide motivation to maintain the position it holds by increasing employee performance. This individual achievement is in line with the company's goal to be able to go forward and survive facing any challenges that hinder the company's development. People who have selfefficacy are people who are able to evaluate themselves to face challenges from the steps they have taken.

Previous research of Burdah (2012) was regarding to the organizational commitment in PT. Jadi Abadi Corak Biscuit. It has changes and decreases of employees commitment obtained data from the existence of several contracts that finnaly suspended many times. It reported that PT. Jadi Abadi Corak Biscuit has 3 production divisions which initially had \pm 5 production divisions. 
This reduction is due to a decrease in commitment to the company. One of the phenomena above is a problem that is developing in a company organization that needs a positive perception of the company's goals. All are charged with assigning tasks to employees with a larger composition. If the employee's perception of this task is negative then the evaluation of results will also be low. Therefore the existence of employee organizational commitment is very close to the existence of self-efficacy in employees in supporting the achievement of goals to be obtained by the company.

The above explanation reinforces the understanding of strong self -abilities in an organization that is very closely related to self-efficacy. Self-efficacy in question is a key component of self-system, which is meant by self-efficacy is not a psychological factor that controls behavior but rather a reference to the structure of cognition that will design the function of perception, evaluation, and regulation of behavior. Bandura (2010) posited that the self-efficacy is a crucial element of personality. This self-efficacy is self-confidence in one's own ability to display behavior that will lead to the expected results.

\section{Research Methods}

A qualitative Research was applied to find the effects of self-efficacy to companies. Qualitative research focuses on the way the world is understood in researchers' minds, usually using abstract scientific concepts and terminology (Hall \& Sandall, 2020). Qualitative methods are no longer regarded as mainly useful because they make it possible to deal with data that (regrettably) are unsuitable for statistical analysis, but are regarded by many researchers nowadays as offering a legitimate method for gaining information about and understanding how human beings function (Cropley, 2019). Data collection was relating to research variables, research samples, research measuring instruments, validity tests, reliability tests, research procedures and data analysis methods. The dependent variable in this study is the Organizational Commitment of Employees (Y) while the independent variable (Self) is Self-Efficacy (X1) and Job Satisfaction (X2). 


\section{Commitment of Employee Organizations}

Organizational commitment is the extent to which employees commit or remain loyal to stay in an organization. Commitment to the organization is measured using a scale compiled based on aspects of commitment to the organization expressed by Mowday (in Spector and Wiley, 1997) as described in Table 2.

Table 1. Operational Definition Dimensions of Employee Organizational Commitment

\begin{tabular}{|l|l|}
\hline \multicolumn{1}{|c|}{ Dimension } & \multicolumn{1}{c|}{ Definition of Operational } \\
\hline $\begin{array}{l}\text { The Acceptance of } \\
\text { Organizational Goals }\end{array}$ & $\begin{array}{l}\text { There is suitability between value held } \\
\text { by the employees and organization. If } \\
\text { the employees feel the organizational } \\
\text { goal meet the desire, the employees will } \\
\text { give all of the commitments to the } \\
\text { organization. }\end{array}$ \\
\hline The desires to work hard & $\begin{array}{l}\text { There is willingness to be serious to the } \\
\text { organization. The employees can feel to } \\
\text { be responsible to build organization and } \\
\text { feel happy to the organization }\end{array}$ \\
\hline $\begin{array}{l}\text { The desire to endure to be } \\
\text { the part of the organization }\end{array}$ & $\begin{array}{l}\text { There is willingness to endure to be a } \\
\text { member of the organization or to be a } \\
\text { part of organization. The employees } \\
\text { have to be ready to take part in } \\
\text { organization and hold the position in } \\
\text { order to make his self to be valued. }\end{array}$ \\
\hline
\end{tabular}

The Employee Organizational Commitment Score is obtained from the total score of all dimensions of the Employee Organizational Commitment scale. High scores on the scale of Employee Organizational Commitment illustrates that the subject has a high Employee Organizational Commitment and conversely a low score obtained illustrates that the subject has a low Employee Organizational Commitment. 


\section{Scale of Organizational Commitment}

The results of the scale analysis of Organizational Commitment scales indicate that of the 18 items there are 9 items that have high different power. There are 9 items that fall (the power difference of items is smaller than 0.36), namely item number $4,5,6,10,11,12,16,17$ and 18 . The results of this item's different power test use the limit of rix $\geq 0.36$. The total item correlation coefficient moves from -0.026 to 0.621 . The reliability results using Cronbach Alpha obtained $\mathrm{rxx}=0.751$ which means that the high level of reliability.

The results of the analysis of employee organizational commitment scale factors show that in the aspect of acceptance of organizational goals, there are 3 items that fall because the loading factor value is below 0.5 , namely item number 4,5 and 6 so that 3 items are obtained with a KMO value of 0.628 , the MSA value moves from 0.564 to 0.628 , and the value of the loading factor that moves from 0.564 to 0.628 , namely items number 1,2 and 3 . Furthermore, in the aspect of the desire to work hard, there are 3 items that fall because the loading factor value is below 0.3 which is item number 1011 and 12 to obtain 3 items with a KMO value of 0.782 , the value of the MSA moves from 0.776 to 0.782 . These items are items number 7, 8 and 9. In the aspect of the Desire to become part of the organization, there are 3 items that were dropped because the MSA value and the loading factor value were below 0.5 , namely item number 16,17 and 18 so that it was obtained 3 items with a KMO value of 0.782 , MSA values moving from 0.564 to 0.782 . These items are items number 13, 14 and 15. The distribution of scale items after the trial is shown in the following table:

Table 2. The Scale of Organizational Commitment after Testing

\begin{tabular}{|l|l|l|l|l|}
\hline No & \multicolumn{1}{|c|}{ Aspects } & \multicolumn{1}{|c|}{$\begin{array}{c}\text { Favorable } \\
\text { Item }\end{array}$} & $\begin{array}{l}\text { Unfavorable } \\
\text { Item }\end{array}$ & Total \\
\hline 1. & $\begin{array}{l}\text { The Acceptance } \\
\text { of } \\
\text { Organizational } \\
\text { Goals }\end{array}$ & $1,2,3$ & - & 3 \\
\hline $\mathbf{2 .}$ & $\begin{array}{l}\text { The Desire to } \\
\text { Work Hard }\end{array}$ & $7,8,9$ & - & 3 \\
\hline $\mathbf{3 .}$ & $\begin{array}{l}\text { The Desire to } \\
\text { Take Part of The } \\
\text { Organization }\end{array}$ & $13,14,15$ & - & 3 \\
\hline Total & 9 & - & 9 \\
\hline
\end{tabular}




\section{Self-Efficiency Scale}

The results of the self-efficacy scale analysis show that of the 24 items there are 12 items that have high power difference. There are 12 items that fall (the difference in power of items is smaller than 0.36 ), namely item number 4,5 ,

$6,10,11,12,16,17,18,22,23$ and 24 . The results of different items are using limit of rix $\geq 0.360$. The total item correlation coefficient moves from -0.180 to 0.716. The reliability results using the Cronbach Alpha results obtained $\mathrm{rxx}=$ 0.829 which means a high level of reliability.The results of the self-efficacy scale factor analysis showed that in the Enactive Mastery Experience aspect, there were 2 items that fell because the loading factor value was below 0.5 , namely item number 4,5 , and 6 .

Thus obtained 4 items with a KMO value of 0.880 , MSA value moves from 0.595 to 0.880 , and the value of the loading factor that moves from 0.595 to 0.880 is item number 1, 2, 3. In the Various Experience aspect, there are 3 items that fall because the loading factor value is below 0.5 , namely item number 10,11 , and 12 . Thus it is obtained 3 items that have a KMO value of 0.880 , the MSA value moves from 0.595 to 0.880 , namely item number 7,8 and 9 . In the Verbal Persuasion aspect there are 3 items that fall because the value of the loading factor is below 0.5 i.e. the item numbers 13,14 and 15. Thus obtained 3 items with a KMO value of 0.880 , the MSA value moves from 0.595 to 0.880 , and a loading factor value from 0.595 to 0.880 is item number 16,17 and 18 and in an Emotional Arousal aspects there are 2 items that fall because the value of the loading factor is below 0.5 namely items number 22, 23 and 24 . Thus it is obtained 3 items with a KMO value of 0.880 , the MSA value moves from 0.595 to 0.880 , and the value of the loading factor of 0.595 to 0.880 , namely items number 19, 20 and 23. Distribution of scale items after the trial is shown in the following table:

Table 3. Scale of Self-Efficacy after Testing

\begin{tabular}{|l|l|l|l|l|}
\hline No & Aspects & $\begin{array}{l}\text { Favorable } \\
\text { Item }\end{array}$ & $\begin{array}{l}\text { Unfavorable } \\
\text { Item }\end{array}$ & Total \\
\hline 1. & $\begin{array}{l}\text { Enactive Mastery } \\
\text { Experience }\end{array}$ & $1,2,3$ & - & 3 \\
\hline 2. & $\begin{array}{l}\text { Various } \\
\text { Experience }\end{array}$ & $7,8,9$ & - & 3 \\
\hline 3. & $\begin{array}{l}\text { Verbal } \\
\text { Persuasion }\end{array}$ & $13,14,15$ & - & 3 \\
\hline 4. & $\begin{array}{l}\text { Emotional } \\
\text { Arousal }\end{array}$ & $19,20,21$ & - & 3 \\
\hline Total & 12 & - & 12 \\
\hline
\end{tabular}




\section{Job Satisfaction Scale}

The results of the Job Satisfaction scale analysis show that of the 36 items there are 17 items that have high differential power. There are 19 items that fall (the power difference of items is smaller than 0.36 ), namely item number 3, 4, 7, $8,11,12,15,16,19,20,23,24,27,28,31,32,35$ and 36.The different power test results of this item use the limitation rix $\geq 0.36$. The total item correlation coefficient moves from 0.102 to 0.797 . The reliability results using Cronbach Alpha obtained $\mathrm{rxx}=0.890$ which means a high level of reliability.

The results of the job satisfaction scale factor analysis show that on the salary dimension, there are 2 items that fall because the loading factor value is below 0.5 namely items number 3 and 4 . Thus obtained 2 items with a KMO value of 0.823 , the MSA value moves from 0.686 to 0.823 , and the loading factor value from 0.686 to 0.823 namely item number 1 and 2 . In the promotion dimension, there are 2 items that fall because the loading factor value is below 0.5 namely items number 7 and 8 . Thus obtained 2 items that have KMO values of 0.823 , MSA value of 0.823 , namely items number 5 and 6 . In the supervision dimension, there are 3 items that fall because the loading factor value is below 0.5, namely item numbers 9, 11 and 12. Thus obtained 1 item that has KMO and MSA values 0.596 , namely item number 10 . On the additional benefit dimension, there are 2 items that fall because the loading factor value is below 0.5 , namely item number 15 and 16. Thus obtained 2 items that have a KMO value of 0.823 , MSA value is 0.686 , namely item number 13 and 14. In the award dimension, there are 2 items that fall because the loading factor value is below 0.5 , namely item number 19 and 20. Thus obtained 2 items that have a KMO value of 0.795 , MSA value of 0.686 namely item number 17 and 18 . On the dimensions of work procedures and regulations, there are 2 items that fall because the loading factor value is below 0.5 , namely item number 23 and 24. Thus obtained 2 items that have a KMO value of 0.823 , MSA value of 0.686 namely items number 21 and 22 . On the dimensions of coworkers, there are 2 items that fall because the loading factor value is below 0.5 namely items number 27 and 28 . Thus it is obtained 2 items that have a KMO and MSA value of 0.95 namely item number 25 and 26. On the dimensions of the work itself, there are 2 items that fall because the loading factor value is below 0.5 , namely item numbers 31 and 32. Thus obtained 2 items that have a KMO and MSA value of 0.686 namely items number 29 and 30. For communication purposes, there were 2 items that fell because the loading factor value was below 0.5 , namely item number 35 and 36. Thus, 2 items were obtained which had a KMO value of 0.795 , MSA value of 0.686 namely item number 33 and 34 . 


\section{Effect of Self-Efficacy Aspects on Organizational Commitment to Employees}

Based on table 25, the calculated $\mathrm{R}$ value of 0.821 shows the correlation between the aspect of the Active Mastery Experience and the organizational commitment of employees. This correlation value is relatively strong (>0.5) and has a positive value so that it can be said the pattern of influence between aspects of the Active Mastery Experience with organizational commitment of employees is unidirectional. Furthermore, for the correlation between aspects of the Enactive Mastery Experience, Various Experience Aspects, Verbal Persuasion Aspects and Arousal Emotional Aspects on employee organizational commitment obtained $\mathrm{R}=0.854 ; \mathrm{p}<0.01$. Thus the influence of aspects of the Enactive Mastery Experience, Various Experience Aspects, Verbal Persuasion Aspects and Emotional Arousal Aspects on employee organizational commitment is unidirectional.

\section{Table 4. Test Result of the Influence of Self-Efficacy Aspects to Employees Organizational Commitment}

\begin{tabular}{|l|r|r|r|r|}
\hline \multicolumn{7}{|c|}{ Model Summary $^{\circ}$} \\
\hline Model & R & R Square & $\begin{array}{c}\text { Adjusted R } \\
\text { Square }\end{array}$ & $\begin{array}{c}\text { Std. Error of } \\
\text { the Estimate }\end{array}$ \\
\hline 1 &, $730^{\mathrm{a}}$ &, 533 &, 523 & 4,016 \\
2 &, $801^{\mathrm{b}}$ &, 642 &, 607 & 3,642 \\
\hline
\end{tabular}

a. Predictors: (Constant), Aspek1_X1

b. Predictors: (Constant), Aspek1_X1, Aspek2_X1, Aspek3_X1,Aspek4_X1

c. Dependent Variable: Komitmen_Organisasional_Karyawan

\section{Employees Organizational Commitment}

\section{Source: SPSS Proccess (2016)}

The coefficient of determination (R2) of the Enactive Mastery Experience Aspect shows a value of 0.533 or $53.3 \%$. This means that variations in employee organizational commitment are influenced by aspects of the Active Mastery Experience by $53.3 \%$ and the remaining $46.7 \%$ are influenced by other aspects besides the Enactive Mastery Experience aspects. 
The coefficient of determination (R2) of the Enactive Mastery Experience Aspect, the Various Experience Aspect, the Verbal Persuasion Aspect and the Arousal Emotional Aspect indicate a value of 0.642 or $6.42 \%$. This means that variations in employee organizational commitment are influenced by the Enactive Mastery Experience Aspect, Various Experience Aspects, Verbal Persuasion Aspects and Arousal Emotional Aspects by 6.42\% and the remaining $3.58 \%$ influenced by other aspects.

Tabel 5.

ANOVA

\begin{tabular}{|ll|r|r|r|r|r|}
\hline Model & & \multicolumn{1}{c|}{$\begin{array}{c}\text { Sum of } \\
\text { Squares }\end{array}$} & df & Mean Square & \multicolumn{1}{c|}{ F } & Sig. \\
\hline 1 & Regression & 828,253 & 1 & 828,253 & 51,359 &, $000^{\circ}$ \\
& Residual & 725,705 & 45 & 16,127 & & \\
& Total & 1553,957 & 46 & & & \\
\hline 2 & Regression & 996,869 & 4 & 249,217 & 18,789 &, $000^{\circ}$ \\
& Residual & 557,089 & 42 & 13,264 & & \\
& Total & 1553,957 & 46 & & & \\
\hline
\end{tabular}

a. Dependent Variable:Komitmen_Organisasional_Karyawan

b. Predictors: (Constant), Aspek1_X1

c. Predictors: (Constant), Aspek1_X1, Aspek2_X1, Aspek3_X1,Aspek4_X1

Source: SPSS Proccess (2016)

Tabel. 6

Coefficients $^{a}$

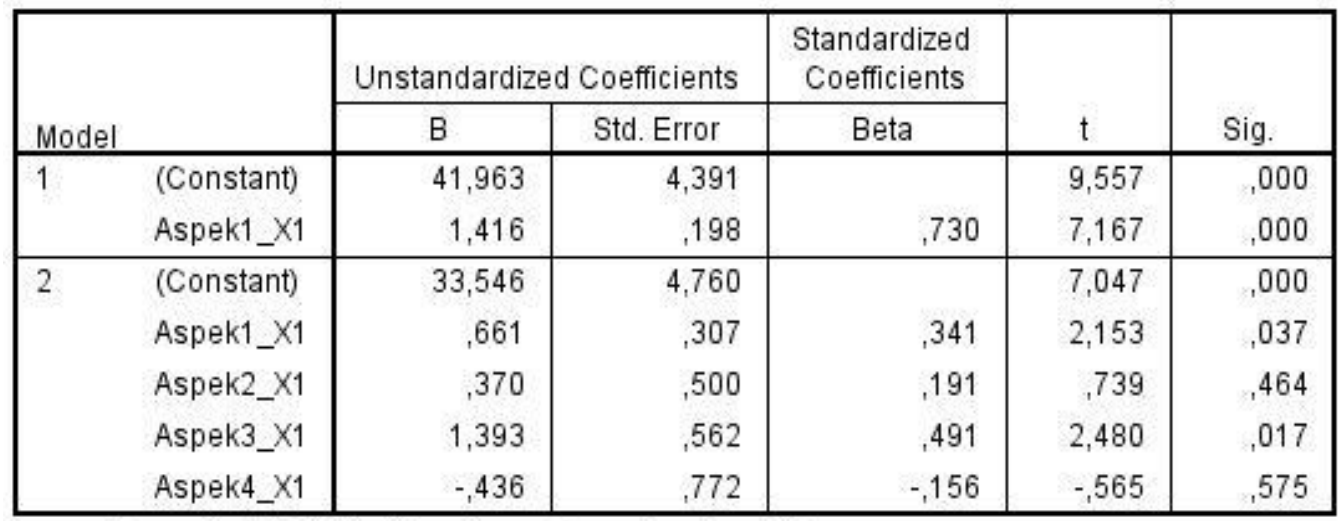

a. Dependent Variable: Komitmen_Organisasional_Karyawan 
Source: SPSS Proccess (2016)

Based on table 26 obtained the equation: $\mathrm{Y}=33.546+0.661 \mathrm{X} 1+$ $0.370 \mathrm{X} 2,+1.393 \mathrm{X} 3-0.436 \mathrm{X} 4$. A constant of 33,546 states that if the Enactive Mastery Experience Aspect the Various Experience Aspect, the Verbal Persuasion Aspect and the Emotional Arousal Aspect are zero, then the organizational commitment of employees is 33,546 units.

Based on the calculation results, it can be concluded that the Enactive Mastery Experience Aspect, Various Experience Aspect, Verbal Persuasion Aspect and Emotional Arousal Aspect have a significant influence on organizational commitment to employees. Furthermore, from table 27, the value of $\mathrm{R}=0.730$ indicates the contribution of the Enactive Mastery Experience aspect to organizational commitment to employees and the value of $R=0.801$ indicates the contribution of the Enactive Mastery Experience, Various Experience Aspects, Verbal Persuasion Aspects and Emotional Aspects of the Arousal towards the organizational commitment to employees .

\section{Effect of Aspects of Job Satisfaction on Organizational Commitment}

Based on table 28 , the calculated $\mathrm{R}$ value of 0.837 shows the correlation between aspects of salary and organizational commitment of employees. This correlation value is relatively strong (>0.5) and has a positive value so that it can be said the pattern of influence between aspects of salary with the organizational commitment of employees is unidirectional. Furthermore, for the correlation between aspects of salary, promotion aspects, aspects of supervision, aspects of additional benefits, aspects of rewards, aspects of procedures and work regulations, aspects of coworkers, aspects of the work itself and communication aspects of organizational commitment to employees obtained $\mathrm{R}$ $=0.965 ; \mathrm{p}<0.01$. Thus the influence of aspects of salary, aspects of promotion, aspects of supervision, aspects of additional benefits, aspects of rewards, aspects of work procedures and regulations, aspects of coworkers, aspects of the work itself and communication aspects of organizational commitment to employees are in the same direction. 
Conclusion

Based on the results of the analysis conducted, it can be concluded that:

- There is a significant positive effect between self-efficacy and job satisfaction on organizational commitment on the employees of PT. PGAS Solution Medan. That is, the higher the level of self-efficacy and job satisfaction, the higher the organizational commitment of employees.

- There is a significant positive effect between self-efficacy on organizational commitment on the employees of PT. PGAS Solution That is, the higher the level of self-efficacy, the higher organizational commitment of employees.

- There is a significant positive effect between job satisfaction on organizational commitment on the employees of PT. PGAS Solution That is, the higher the level of job satisfaction, the organizational commitment of employees is also higher.

\section{Disclosure statement}

No potential conflict of interest was reported by the authors.

Contact Information.

Email address:eka@gmail.com 


\section{References and notes:}

Al-Jabari, B. \& Ghazzawi, I. (2019). Organizational Commitment: A Review of the Conceptual and Empirical Literature and a Research Agenda. International Leadership Journal, 11(1), 78-119.

Andrew, A. (2017). Employees' Commitment and Its Impact on Organizational Performance. Asian Journal of Economics, Business and Accounting, 5(2), 1-13.

Bandura. (2010). Self-Efficacy (The Exercise Of Control. New York, W. H. Freeman and Company.

Burdah, I. (2012). Relationship between Self Efficacy and Employee Organizational Commitment at PT. Jadi Abadi Corak Biscuit Surabaya. Thesis; Universitas Islam Negeri Maulana Malik Ibrahim. http://etheses.uinmalang.ac.id/2280/1/08410038_Pendahuluan.pdf (accessed on 22 August 2016).

Cropley, A. J. (2019). Qualitative research methods: A practice-oriented introduction for students of psychology and education. Riga, Latvia: Zinātne. (open access - doi: 10.13140/RG.2.1.3095.6888)

Hall, J. \& Sandall, J. (2020). Time and Qualitative reasearch : Principles, Pitfalls and Perils. January 2020 -The Sixth Annual Qualitative Research Symposium:'Tick Tock: Unpacking Temporal Aspects of Qualitative Inquiry'.

Ifdil, I., Apriani, R., Yendi, F. M., \& Bolo Rangka, I. (2016). Level of Students` Self-Efficacy Based on Gender. Counsedu: The International Journal of Counseling and Education, 1(1), 29-33. DOI: 10.23916/29-33.0016.11-i41b

Irefin, P. \& Mechanic, M.A. (2014). Effect of Employee Commitment on Organizational Performance in Coca Cola Nigeria Limited Maiduguri, Borno State. IOSR Journal Of Humanities And Social Science, 9(3), 33-41.

Mohamud, S.A. Husein, J.M. Mohamud, S.A. (2018). The Effect Of Employee Commitment On Organizational Effectiveness: Case Study Of Waaya Arag And Beder Electronic Companies In Mogadishu- Somalia. International Journal of Current Research ,10(3), 67333-67338

Spector, Paul E. (1997). JobSatisfaction; Application, Assessment, Causes and Consequences.

Tuna, M.; Ghazzawi, I.; Tuna, A.; \& Catir, O. (2016). Perceived External Prestige and Organizational Deviance: The Case of Turkey's Hospitality Industry. International Journal of Contemporary Hospitality Management, 28(2), 366- 396.

Yokoyama S. (2019). Academic Self-Efficacy and Academic Performance in Online Learning: A Mini Review. Front. Psychol. 9, 2794. doi: 10.3389/fpsyg.2018.02794 